PART I. DISEASES AND PROBLEMS DISTINGUISHED BY WHO AND FAO DZIAŁ I. CHOROBY I PROBLEMY WYRÓŻNIONE PRZEZ WHO I FAO

\title{
EFFECT OF SELENIUM ON BREAST CANCER IN WOMEN - PART I
}

\section{WPEYW SELENU NA ZAPOBIEGANIE NOWOTWOROM GRUCZOŁU PIERSIOWEGO U KOBIET - CZĘŚĆ I}

\author{
Katarzyna Sygit $^{1(\mathrm{~B}, \mathrm{D}, \mathrm{E}, \mathrm{F}, \mathrm{G})}$, Krzysztof Sieja $^{2(\mathrm{~A}, \mathrm{~B}, \mathrm{C})}$, Marian Sygit $^{3(\mathrm{~B}, \mathrm{D}, \mathrm{E}, \mathrm{F})}$, Katarzyna Pasierbiak $^{4(\mathrm{D}, \mathrm{E})}$ \\ ${ }^{1}$ Health Promotion Department, Faculty of Physical Culture and Health Promotion, University of Szczecin, Poland \\ ${ }^{2}$ Institute of Physical Culture, State Higher Vocational School in Wałcz, Poland \\ ${ }^{3}$ Physical Education Department, Faculty of Physical Culture and Health Promotion, Universty of Szczecin, Poland \\ ${ }^{4}$ Poddębickie Centrum Zdrowia SP. z o.o. Hospital, Vis Salus Foundation for the Promotion of Mental and Somatic \\ Health, Poland
}

Authors' contribution

Wkład autorów:

A. Study design/planning

zaplanowanie badań

B. Data collection/entry

zebranie danych

C. Data analysis/statistics

dane - analiza i statystyki

D. Data interpretation interpretacja danych

E. Preparation of manuscript przygotowanie artykułu

F. Literature analysis/search wyszukiwanie i analiza literatury

G. Funds collection

zebranie funduszy
Tables: 0

Figures: 0

References: 24

Submitted: 2018 Feb 02

Accepted: 2018 March 15

\section{Summary}

Background. Breast cancer is the most common malignant tumour in women in Poland. To reduce the risk of breast cancer, appropriate prevention is necessary. Numerous studies conducted over many years in Poland and throughout the world have demonstrated a significant effect of selenium on prevention of disease, including breast cancer in women. The following paper aims to present the literature on effects of selenium (Se) on prevention of breast cancer in women.

Material and methods. Based on national and international literature, the paper presents information on the role of selenium (Se) in prevention of breast cancer in women.

Results. Numerous studies conducted in research centres in Poland and abroad have shown that female patients with breast cancer and individuals with gastrointestinal cancer have significantly lower selenium concentration in their blood serum and whole blood, as well as significantly lower GSH - Px activity in plasma and red blood cells, compared to healthy women. Low selenium concentration may indicate an increased risk of breast cancer. Selenium is an essential co-factor in the production of antioxidant enzymes and may affect the development of cancer. Clinical trials which assessed selenium content in food showed that its supplementation reduced cancer mortality.

Conclusions. Results of numerous national and prospective international studies indicate that low selenium intake and/or concentration in serum/plasma/nails is a high-risk marker of the majority of cancers, including breast cancer in women.

Keywords: prevention, selenium, cancer, breast cancer

\section{Streszczenie}

Wprowadzenie. Nowotwór gruczołu piersiowego jest najczęstszym nowotworem złośliwym $\mathrm{u}$ kobiet $\mathrm{w}$ Polsce. Aby zmniejszyć ryzyko zachorowania na raka piersi niezbędna jest odpowiednia profilaktyka. Liczne badania prowadzone od wielu latw Polsce i na świcie pokazały znaczące działanie selenu w profilaktyce chorób nowotworowych - w tym nowotworów piersi u kobiet. Celem niniejszej pracy jest przedstawienie w świetle literatury przedmiotu wpływu selenu (Se) na zapobieganie nowotworom gruczołu piersiowego u kobiet.

Materiał i metody. W pracy zaprezentowano na przykładzie dostępnej literatury przedmiotu (krajowej jak i zagranicznej) informacje dotyczące roli selenu (Se) w profilaktyce nowotworu gruczołu piersiowego u kobiet.

Wyniki. Liczne badania prowadzone w ośrodkach zarówno w Polsce jak i zagranicą wykazały, że u pacjentek z rakiem gruczołu piersiowego oraz u osób z nowotworami przewodu pokarmowego stwierdza się znamiennie niższą koncentrację selenu w surowicy, w pełnej krwi oraz znamiennie niższą aktywność GSH - Px w osoczu i krwinkach czerwonych w porównaniu do kobiet zdrowych. Niska koncentracja selenu może być wskaźnikiem zwiększonego ryzyka raka gruczołu piersiowego. Selen jest ważnym kofaktorem w produkcji enzymów antyoksydacyjnych i może wpływać na przebieg procesu nowotworowego. $\mathrm{W}$ próbach klinicznych związanych z oceną zawartości Se w pożywieniu wykazano, że suplementacja Se zmniejsza śmiertelność z powodu raka.

Wnioski. Wyniki licznych badań prospektywnych krajowych i zagranicznych wskazują, iż niskie spożycie selenu i/lub stężenia tego pierwiastka w surowicy/osoczu/paznokciach jest markerem wysokiego ryzyka zachorowania na większość nowotworów, w tym nowotworu gruczołu piersiowego u kobiet.

Słowa kluczowe: prewencja, selen, choroba nowotworowa, nowotwór piersi

Sygit K, Sieja K, Sygit M, Pasierbiak K. Effect of selenium on breast cancer in women - part I. Health Prob Civil. 2018; 12(2): 71-77. https://doi.org/10.5114/hpc.2018.74586

Address for correspondence / Adres korespondencyjny: Katarzyna Sygit, Department of Health Promotion, Faculty of Physical Education and Health Promotion University of Szczecin, Poland, Cukrowa 12, 71-004 Szczecin, Poland, e-mail: katarzyna.sygit@usz.edu.pl, phone: +48 914443492

Copyright: (C) Pope John Paul II State School of Higher Education in Biała Podlaska, Katarzyna Sygit, Krzysztof Sieja, Marian Sygit, Katarzyna Pasierbiak. This is an Open Access journal, all articles are distributed under the terms of the Creative Commons Attribution-NonCommercial-ShareAlike 4.0 International (CC BY-NC-SA 4.0) License (http://creativecommons.org/licenses/by-nc-sa/4.0/), allowing third parties to copy and redistribute the material in any medium or format and to remix, transform, and build upon the material, provided the original work is properly cited and states its license. 


\section{Introduction}

High incidence of breast cancer in women motivates numerous research teams to look for causes of morbidity, as well as to search for preventive methods and effective therapeutic measures. Numerous studies conducted over many years in Poland and throughout the world have demonstrated a significant effect of selenium in the prevention of cancer, including breast cancer in women.

It has been proved that the chemical transformation of selenium into a methylated metabolite is an important step in achieving anti-cancer prevention. The studies based on carcinogenesis of breast cancer in an experimental model in rats suggest that methyl cysteine is a precursor of endogenous formation of methyl selenol, which enables blocking the clonal expression of precancerous lesions in the mammary gland [1,2]. The obtained results confirm that cellular intervention of selenium takes place in the early stages of carcinogenesis. Selenium reduces transformation of cancer cell colonies in vivo. Additionally, methyl selenecysteine (MSC) facilitates apoptosis. The same cellular response was obtained in studies on pre-cancerous cells of human breast cancer. An analysis of cDNA microarrays (a microarray - applicable to the study of a gene sequence) indicates that selenium is active in numerous molecular cell sites [1]. The following paper aims to present the literature on effects of selenium (Se) on prevention of breast cancer in women.

\section{Selenium versus breast cancer in women}

Breast cancer is the most common malignant tumour in women in Poland, where it accounts for about $12 \%$ of all cancers. It is the most common cancer among women in terms of the cause of death [3]. Every year, 12,000 new cases of this malignant tumour are diagnosed in Poland. Additionally, it causes 5000 deaths annually. It is estimated that currently 50,000-60,000 Polish women are affected by this type of cancer. It is expected that every $14^{\text {th }}$ Polish woman will develop breast cancer in the future, while the incidence in most European countries is even higher. For example, in the United Kingdom - a country with almost twice the rate of incidence of breast cancer - every $9^{\text {th }}$ woman will develop it. In contrast to other cancers, the chance to cure breast cancer increases significantly if it is diagnosed at an early stage. In Poland, Early Breast Cancer Detection Program was introduced in 2006, and there are already some visible changes in the structure of deaths. Thanks to the introduction of free screening tests for early detection of breast cancer, the number of deaths in recent years has remained stable [4].

The majority of studies on the relationship between selenium and cancer development focus on experimental, epidemiological and clinical research on breast cancer. Schrauzer et al. investigated the impact of diet which mimicked the diet of American, Bulgarian and Japanese women concerning selenium content on the incidence of virus-induced breast cancer in mice. The That study aimed to investigate the impact of a diet which mimicked the diet of a typical American, Bulgarian and Japanese woman, on the development of nodules in C3M mice after applying an oncogenic MMTV virus to mice's mammary gland. The largest number of nodules appeared in the group of mice which followed the American diet, i.e. rich in meat and fats, with little selenium (0.15 ppm). The fewest nodules developed in the group of mice on the Bulgarian diet. This correlates with epidemiological conclusions about lower incidence of breast cancer amongst Bulgarians, compared to residents of other European countries and the United States. The Bulgarian diet contained more selenium ( $0.25 \mathrm{ppm})$, less fat, meat, sugar, and more complex carbohydrates (cereal) than the American diet [5]. In mice on the Japanese diet, there was also a delayed occurrence of breast cancer, and its frequency was lower. In the Japanese menu, fish was the primary source of selenium. However, selenium contained in fish is not easily available biologically. Supplementation of selenium in the diet of Japanese women also reduced the incidence of breast cancer. Based on these studies, the authors propose recommendations to reduce the incidence of breast cancer through diet [6].

Studies by Pawłowicz et al. showed that female patients with breast cancer and individuals with gastrointestinal cancer had significantly lower selenium concentration in blood serum and whole blood, as well as significantly lower GSH - $\mathrm{P}_{\mathrm{x}}$ activity in plasma and red blood cells, compared to healthy women. Low selenium concentration may indicate an increased risk of breast cancer [7].

Clinical studies conducted by Krsnjavi and Beker showed that selenium level in patients with breast cancer, compared to women with fibrocystic cysts and healthy women, was significantly lower. The above-mentioned authors concluded that identifying selenium level in blood serum may be useful as a non-invasive indicator in the clinical assessment of malignancy of breast cancer patients. Krsnjavi and Beker studied the level of selenium in blood serum in women with breast cancer, with mastopathy and in healthy subjects. There was no significant difference in the level of selenium in women with fibrocystic breast changes and healthy women. These results suggest that determination of selenium level in serum may be used as a non-invasive diagnostic parameter in clinical assessments of malignant breast tumour [8]. 
The same inverse correlation between selenium concentration in blood serum vs breast cancer incidence and significantly lower mean selenium concentration in serum of cancer patients vs the control group was found by Mc Connell et al. [9]. However, Basu et al. believed that the low level of A and E vitamins, beta-carotene and selenium in patients with breast cancer may be a consequence of the disease - rather than a symptom of cancer $[10]$.

Epidemiological studies conducted in Sweden by a group of oncologists under the supervision of Hardell showed the preventive effects of selenium on the occurrence of breast cancer. The above-mentioned effect was more pronounced in post-menopausal women. For women before menopause, this trend was also observed, but it was not statistically significant, which may indicate that both groups vary - at least partly - regarding carcinogenesis mechanisms. GSH - $\mathrm{P}_{\mathrm{x}}$ level in red blood cells was not a marker of breast cancer risk and did not correlate with the level of selenium in serum [11].

In an experimental development of breast cancer in animals, a chemical compound (abbreviated to DMBA) was applied. DMBA induces breast cancer in animals. Rats treated with DMBA developed breast cancer, as DMBA acts as a carcinogen. In 1992, in experimental studies on rats, Ip et al. demonstrated that chemically induced breast cancer development may be prevented by the use of 7,12-dimethylbenz(a)anthracene (DMBA) by regular use of garlic enriched with selenium [1].

In various types of malignant tumours, the expression of selenoproteins is reduced, especially when the level of selenium is low in serum. At this point, a unique role of CHEK kinases (checkpoint kinases) in the regulation of the cell cycle should be emphasized. CHEK kinases are essential proteins which delay progression of the cell cycle in normal and damaged cells. They can affect three phases of the cell cycle: $G_{1}, S$ and $G_{2}$. It was found that the weakening of the CHEK2 gene function was associated with a two-fold increase in breast cancer in Ashkenazi Jewish women. Hereditary breast and ovarian cancers are more common in the Ashkenazi Jewish population than in other ethnic groups, which is determined genetically. CHEK2 is a gene responsible for the susceptibility to cancers of various organs. Mutations in the CHEK2 gene are associated with an increased risk of multiple organ cancers [12].

The observed risk increase is further deepened in case of a positive family history of cancer. A handful of studies indicate that the risk of cancer in individuals who carry CHEK2 mutation may be modified by many factors such as [13]:

- Family interview;

- Hormonal disorders;

- Other genetic factors;

- Environmental factors;

- Composition of the consumed nutritional products.

Various antioxidant agents contained in the diet have a significant effect as they serve as cancer prevention factors by reducing the oxidative state which is associated with cancer. The study results suggest that many factors - on their own or in combination with traditional chemotherapeutic agents - prevent the development of cancer by inhibiting the formation of cancer and contributing to its curing. Reduction of cancer risk and lack of cytotoxicity associated with high consumption of fruit and vegetables suggest that specific concentrations of antioxidants from food sources may have chemo-preventive effects on cancer. Selenium may be one of the critical chemo-preventive factors that lower the risk of cancer in individuals who carry CHEK2 mutation [14].

Selenium is an essential micro-nutrient, and its concentration in serum and tissues is regulated by homeostasis mechanisms, which have not been fully understood yet. Selenium exists in the body in the form of selenocysteine, which is a component of selenoproteins; it plays an important structural and enzymatic role, such as antioxidant activity. Oxidative cell damage is a general mechanism of cell and tissue damage. Oxidative stress in tissues is assumed to play an significant role in carcinogenesis. Therefore, identification of selenium concentration in cancerous tissues and surrounding healthy tissues is a particularly important issue. Selenium concentration in the breast cancer tissue in women and the surrounding unchanged tissues was investigated by Charalabopoulos et al. [15].

These authors stated that the concentration of selenium in women with breast cancer was $42.5 \pm 7.5 \mu \mathrm{g} / \mathrm{l}$ in blood serum, while $67.6 \pm 5.36 \mu \mathrm{g} / \mathrm{l}$ in the control group, selected according to age. The concentration of selenium in breast cancer tissue was $2660 \pm 210 \mathrm{mg} / \mathrm{g}^{-1}$ of the tissue, while in healthy tissue adjacent to cancer, it was $680 \pm 110 \mathrm{mg} / \mathrm{g}^{-1}(\mathrm{P}<0.001)$. Thus, the concentration of selenium in the breast cancer tissue was four times higher than in the adjacent tumor-free tissue. This supports the hypothesis that the local effect of selenium in cancer tissue is one of the crucial mechanisms of anti-tumour activity. This idea is consistent with the antioxidant functions of selenium. It is not yet clear whether the increase in selenium concentration in cancer tissue is responsible for the decrease in selenium concentration in serum, which is usually found in patients with breast cancer or whether reduced selenium concentration in serum precedes the development of breast 
cancer. Identification of a decreased selenium concentration in the blood serum of women with breast cancer and increased selenium concentration in breast cancer tissues is a discovery of great scientific importance. The above-mentioned changes may reflect some of the body's defence mechanisms against carcinogenesis in the breast gland.

Additionally, Charalabopoulos et al. studied the concentration of carcinoma embryonic antigen (CEA) in blood serum in women with breast cancer and a selected control female group. The concentration of CEA in the serum of women with breast cancer was $10 \pm 1.7 \mathrm{ng} / \mathrm{ml}$ (norm $<2.5 \mathrm{ng} / \mathrm{ml}$ in healthy non-smokers and $<3.5 \mathrm{ng} /$ $\mathrm{ml}$ in healthy smokers). In contrast, CEA concentration in serum in the control group was $2.3 \mathrm{ng} / \mathrm{ml}(\mathrm{P}<0.001)$. There was a highly significant difference $(\mathrm{P}<0.001)$ in selenium concentration in serum and CEA level in serum $(<0.001)$ between the group of women with breast cancer and the control group of healthy women. There was also an inverse correlation between selenium concentration in serum and CEA level in serum in both groups. Low selenium concentration in serum amongst women with breast cancer may be attributed either to insufficient selenium intake with food, or the deposition of this microelement in breast cancer cells, or simultaneous occurrence of both of these processes [2,15].

Another significant term in oncology concerning breast cancer is protein kinase erb-2. It is a protein, coded by a gene that is often called HER2 (from human epidermal growth factor receptor 2), or HER2/neu. HER2 belongs to human epidermal growth factor receptors. HER2/neu is a human epidermal growth factor receptor 2 [16].

It has been shown that the amplification or overexpression of this oncogene plays a vital role in the development and progression of aggressive breast cancers. In recent years, this protein has become an important biomarker and the target of therapy in approximately $30 \%$ of women with breast cancer. Amplification or overexpression of the HER2/neu gene occurs in about $15-30 \%$ of breast cancers and is closely associated with a higher rate of relapse and poor prognosis. HER2 is the target of a monoclonal antibody called trastuzumab (proprietary name Herceptin). Trastuzumab is effective when HER2 is overexpressed in cancer tissue. A significant effect at the subcellular level is binding HER2 by trastuzumab and the growth of p27 protein, which inhibits cell proliferation [17].

Approximately 10-15 percent of breast cancer patients are diagnosed with the so-called 'triple negative breast cancer' (TNBC). This subtype of breast cancer is characterised by lack of expression of estrogen receptors, progestagen receptors, and the physiological HER2 receptor present on its surface (no HER2 receptor overexpression). It is a more aggressive form of breast cancer than cancer with the expression of hormone receptors. This subtype of breast cancer is particularly aggressive, associated with rapid relapses after treatment, a more frequent occurrence of distant metastases, and shorter survival compared to other types of breast cancer. The treatment of triple negative breast cancer depends on the stage of the disease. The choice of therapy is influenced by the presence of metastases, the size of the primary tumour and the results of detailed pathological tests, such as the degree of malignancy of the tumour, which determines the rate of tumour cell division. The treatment of triple negative breast cancer involves surgical methods, radiotherapy and chemotherapy [18].

In the treatment of TNBC patients, it is important to stop the process of formation of the network of blood vessels that supply nutrients to the tumour tissue (so-called angiogenesis). Most cases of triple negative breast cancer occur during the pre-menopausal period. Because of the 'triple negative nature' of cancer, TNBC patients are not candidates for hormone therapy or anti-HER2 therapy. Thus, their therapeutic options are insufficient. As already mentioned, there is not a large arsenal of drugs which may be used, as hormone therapy and drugs effective on HER2 are excluded. Therefore, the average survival time in this group is still shorter than in patients with other types of breast cancer. Chemotherapy is usually the standard procedure. The first line of drugs used in chemotherapy are taxanes, such as paclitaxel or docetaxel - alone or in combination with anthracyclines. Treatment of advanced breast cancer involves taxane drugs: paclitaxel (PXL), isolated initially from yew bark Taxus brevifolia, and its derivative, docetaxel (DXL). Docetaxel (proprietary name: Taxorete, Company: Teva Pharma) is a cytostatic drug belonging to the semi-synthetic taxane group, a derivative of the substance obtained from the common yew needle (Taxus baccate). Docetaxel breaks the microtubule network, which is necessary for vital cell functions during mitosis and interphase $[3,18]$.

Phase II clinical trials showed a relatively high taxane activity in first-line therapy, but also in the $2^{\text {nd }}$ and $3^{\text {rd }}$ line of treatment in patients with anthracycline resistance. Taxanes and anthracyclines have a different mechanism of anti-cancer activity. Taxanes bind with tubulin, initiating the formation of microtubules, and then inhibit their depolymerisation. Additionally, they affect other biological processes, i.e. they stimulate apoptosis and inhibit angiogenesis, cell motility and metalloproteinase production, which may further increase their anticancer effects. Metalloproteinases belong to the super-family of proteolytic enzymes, which contain a catalytic zinc ion in their characteristic centre. The increase in metalloproteinases activity is associated with cancer. 
Anthracyclines inhibit topoisomerase II, which in turn leads to increased DNA damage. A pressing issue is the toxicity of taxane-containing patterns (fatigue, asthenia, neurotoxicity - usually in the form of peripheral neuropathy). The occurrence of neurotoxicity depends on the dosage of the drug. Although patients tend to have a rapid favourable response to the use of taxanes, the development of early resistance to this group of drugs is also common. Hence the need to look for factors that could efficiently facilitate taxanes' efficiency and help overcome resistance. This is an urgent task, necessary for effective treatment - especially of the 'triple negative breast cancer' (TNBC) [19].

Selene is an effective low-toxicity anticarcinogen. Anti-cancer effect of selenium depends on its form and dosage. Methylselenic acid (MSA) is a potent compound containing 2. generation selenium. To date, only two experimental studies on mice regarding the use of methylselenic acid in combination with paclitaxel in the treatment of 'triple negative' breast cancer have been published. These are the works by Qi et al. [18] and Zeng et al. [20]. Qi et al. The authors concluded that methylselenic acid significantly facilitates the anti-cancer effect of paclitaxel in the treatment of 'triple negative breast cancer'. Paclitaxel is an organic chemical compound from the terpene alkaloids group of taxanes, with a cytostatic effect. It was introduced to oncological treatment for the first time in 1992 under the name Taxol (Taxol; company: Bristol-Myers Squibb, BMS). Methylselenic acid shows synergy with paclitaxel, facilitating the inhibitory effect of paclitaxel on the development of breast cancer [18].

The above-mentioned authors came to the following conclusions:

- MSA (methylselenic acid) synergistically facilitates the efficacy of paclitaxel in suppressing tumor growth by increasing the inhibitory effect of paclitaxel on tumour cells;

- MSA and paclitaxel synergistically inhibit tumour cell proliferation;

- MSA facilitates the effects of paclitaxel in the paclitaxel-induced suppression of the $G_{2} / M$ phase cell cycle.

- MSA facilitates paclitaxel-induced apoptosis. Paclitaxel-induced $G_{2} / M$ inhibition generally leads to increased apoptosis.

The results of experimental studies conducted by Li et al., on combined treatment with methylselenocysteine (MSC) with tamoxifen (Tamoxifenum) of breast cancer are very significant. In mice with transplanted MCF-7 breast cancer cell line, the combined treatment with MSC and tamoxifen inhibited the development of breast cancer by increasing apoptosis and reducing tumor angiogenesis [21]. Organic selenium may provide additional therapeutic benefits when used in combination with tamoxifen - both in prevention, as well as in complementary therapy.

Combination treatment with methylselenocysteine and tamoxifen (Tamoxifenum) used to treat transplantable breast cancer in mice inhibited the growth of cancer synergistically. This effect was more significant than when MSC alone or tamoxifen alone (Tamoxifenum) were used. The combination of MSC + tamoxifen significantly reduced the number of alpha (ERò) estrogen receptors, progesterone receptors (PR), D1 cyclin and the Ki67 index in cancer tissues. Additionally, the microvessel density decreased in the tumour, and apoptosis processes increased. Importantly, the methylselenic acid, which acts synergistically with tamoxifen, induces apoptosis via caspases in breast cancer cells. Caspases belong to the cysteine proteases family and play an important role in apoptosis (programmed cell death). These proteins are referred to as 'executioners' because of their role in the cell $[20,21]$.

Selenium is an essential co-factor in the production of antioxidant enzymes and may affect the course of the cancer process. Clinical trials which assessed selenium content in food showed that its supplementation reduced cancer mortality. Harris et al. investigated whether dietary intake of selenium was associated with survival among 3,146 women who were diagnosed with invasive breast cancer, based on a population study conducted on a group of women in Sweden who underwent mammography (Swedish Mammography Cohort). An inverse relationship was found between selenium intake with food and specific mortality due to breast cancer and overall mortality. Women who had higher selenium intake displayed lower mortality rates compared to women who consumed smaller amounts of selenium in food $(\mathrm{P}=0.009)$. Comparing women with higher and lower doses of selenium in their diet, there was an inverse relationship between dietary selenium intake and mortality due to breast cancer. This correlation seems to be the largest among women who never smoked cigarettes $(\mathrm{P}=0.01)$. The results of the above authors' research suggest that selenium intake before the diagnosis of breast cancer may improve the mortality specific for this type of cancer, as well as the overall mortality rate of women [22].

\section{Conclusions}

Numerous epidemiological studies carried out in various countries, especially in the Scandinavian countries and the United States, showed a negative correlation between the amount of selenium consumed and the incidence of cancer in humans. The studies also showed a lower concentration of this microelement in the blood 
of patients with oncological diseases, in comparison to the values obtained in healthy subjects $[2,7,9,12,15,23,24]$. Data from a meta-analysis of 49 prospective studies showed that the overall risk of cancer was 31\% lower, and the risk of death from cancer was $45 \%$ lower in the groups with the highest exposure to selenium, compared to groups with the lowest exposure to selenium [23]. To sum up, the results of above-mentioned prospective studies indicate that low selenium intake and/or concentration of selenium in serum/plasma/nails is a high-risk marker of the majority of cancers.

\section{References:}

1. Ip C, Daniel FB. Effects of selenium on 7,12-dimethylbenzanthra dimethylbenz(a)anthracene - induced mammary carcinogenesis and DNA adduct formation. Cancer Res. 1985; 45: 61-65.

2. Ip C, White G. Mammary cancer chemoprevention by inorganic and organic selenium: single agent treatment or in combination with vitamin $\mathrm{E}$ and their effects on in vitro immune functions. Carcinogenesis 1987; 8(12): 1763-1766.

3. Bobrowska-Korczak B, Krajnowska S, Tokarz A. Geny H-RASI i K-RASI jako potencjalne markery raka piersi. Bromat. Chem. Toxykol. 2012; 45: 586-589.

4. Kalinowski P, Bojakowska U. Epidemiologiczna ocena zachorowalności i umieralności na raka piersi w województwie lubelskim w latach 2000-2011, z uwzględnieniem uczestnictwa w skrinningu. Medycyna Ogólna i Nauki o Zdrowiu. 2015; 21(50): 235-239 (in Polish).

5. Schrauzer GN, Malebaar T, Kuehn K, Waller D. Effect of simulated American, Bulgarian and Japanese human diets and of selenium supplementation on the incidence of virally induced mammary tumors in female mice. Biol. Trace Elem. Res. 1989; 20: 169-178.

6. Gerber LH, Stout N, Mc Garvey C, Soballe P, Shieh CY, Diao G, et al. Factors predicting clinically significant fatigue in women following treatment for primary breast cancer. Support Care Cancer 2011; 19(10): 1581-1591. https://doi.org/10.1007/s00520-010-0986-7.

7. Pawłowicz Z, Zachara BA, Trafikowska U, Maciąg A, Marcheluk E, Nowicki A. Blood selenium concentrations and glutathione peroxidase activities in patients with breast cancer and with advanced gastrointestinal cancer. J. Trace Elem. Electrolytes Health Dis. 2003; 5: 275-279.

8. Krsnjavi H, Becker D. Selenium and immunoglobulins. Trace Elem. Med. 1991; 8: 161-166.

9. Mc Connell KP, Jager RM, Bland KI, Blotchy AJ. The relationship of dietary selenium and breast cancer. J. Surg. Oncol. 2008; 15: 67-73. https://doi.org/10.1016/0048-9697(90)90331-N.

10. Basu TK, Hill GB, Ng D, Aboli E, Temple N. Serum vitamins A and E, beta - carotene, and selenium in patients with breast cancer. J. Amer. Coll. Nutr. 2012; 8: 524-529.

11. Hardell L, Danell M, Angqvist CA, Marklund SL, Fredriksson, Zakari AL, et al. Levels of selenium in plasma and glutathione peroxidase in erythrocytes and the risk of breast cancer. A case - control study. Biol. Trace Element Research 1993; 36: 99-108. https://doi.org/10.1007/BF02783168

12. Shaag A, Walsh T, Renbaum P. Functional and genomic approaches reveal an ancient CHEK2 alleleassociated with breast cancer in the Ashkenazi Jewish population. Hum. Mol. Genet. 2005; 14: 555-563. https://doi.org/doi.10.1093/hmg/ddi052

13. Bratakos MS, Kanaki HC, Waite-Vasiliou A, Ioannou PV. The nutritional selenium status on healthy Greeks. Sci. Total Environ. 2009; 91: 161-176. https://doi.org/10.1016/0048-9697(90)90296-7

14. Cybulski C, Górski B, Huzarski T, Masojć B, Mierzejewski M, Dębniak T, et al. CHEK2 is a multiorgan cancer susceptibility gene. Am. J. Hum. Genet. 2004; 74: 1131-1135. https://doi.org/10.1086/426403

15. Charalabopoulos K, Kotsalos A, Batistatou A, Charalabopoulos A, Vezyraki P, Peschos D, et al. Selenium in serum and neoplasic tissue in breast cancer: correlation with CEA. Br. J. Cancer 2006; 95: 674-676. https://doi.org/10.1038/sj.bjc.6603292

16. Nowacka-Zawisza M, Krajewska WM. Potrójnie negatywny rak piersi: molekularna charakterystyka i potencjalne strategie. Postępy Hig. Med. Dośw. 2013; 67: 1090-1097.

17. https://en.wikipedia.org/wiki/HER2/neu (cited 2017 Oct 26)

18. Qi Y, Fu X, Xiong Z, Zhang H, Hill SM, Rowan BG, et al. Methylselenic acid enhances paclitaxel efficacy for the treatment of triple-negative breast cancer. Plos One 2012; 720 : e3159.

https://doi.org/doi: 10.1371/journal.pone.0031539

19. Krasińska L, Jassem J. Rola taksanów w leczeniu zaawansowanego raka piersi. Nowotwory 2003; 53(2): 176-180 (in Polish).

20. Zeng Q, Yang Z, Gao YJ, Yuan H, Cui K. Treating triple-negative breast cancer by a combination of rapamycin and cyclophosphamide; in vivo bioluminescence imaging study. Eur. J. Cancer 2010; 46: 1132-1143.

https://doi.org/ 10.1016/j.ejca.2010.01.014 
21. Li Z, Carrier L, Belame A, Thiyagarajah A, Salvo VA. Combination of methylselenocysteine with tamoxifen inhibits MCF-7 breast cancer xenografsin nude mice through elevated apoptosis and reduced angiogenesis. Breast Cancer Res. Treat. 2009; 118: 33-43. https://doi.org/10.1007/s10549-008-0216-x

22. Harris HR, Bergkvist L, Wolk A. Randomized, double-blind, placebo-controlled, phase III chemoprevention. Selenium intake and breast cancer mortality in a cohort of Swedish women. Breast Cancer Res. Treat. 2012; 134(3): 1269-1273. https://doi.org/10.1007/s10549-012-2139-9

23. Drozda R, Trzciński R, Rutkowski M, Grzegorczyk K, Dziki Ł. Concentrations of antioxidative trace elements - selenium and zinc - in patients with sigmoid or rectal cancers. Gastroenterol. Pol. 2008; 15(6): 391-395.

24. Huzarski T, Byrski T, Gronwald J, Zajączek S, Kowalska E, Górski B, et al. Obniżenie ryzyka raka piersi i jajnika u nosicielek mutacji genu BRCA1 poprzez suplementacje diety selenem. Profilaktyka i zdrowie w onkologii, Świdnica 2000-2006; 2 Konferencja Naukowa pt.: Genetyka w onkologii, Świdnica, 2006. Sprawozdania z konferencji, szkoleń i badań. Wrocław, 2007. p. 46-56 (in Polish). 